\title{
Lumen
}

Selected Proceedings from the Canadian Society for Eighteenth-Century Studies

\section{Flora Feministica: Reflections on the Culture of Botany}

\section{Ann B. Shteir}

Volume 12, 1993

URI : https://id.erudit.org/iderudit/1012589ar

DOI : https://doi.org/10.7202/1012589ar

Aller au sommaire du numéro

Éditeur(s)

Canadian Society for Eighteenth-Century Studies / Société canadienne d'étude du dix-huitième siècle

ISSN

1209-3696 (imprimé)

1927-8284 (numérique)

Découvrir la revue

Citer cet article

Shteir, A. B. (1993). Flora Feministica: Reflections on the Culture of Botany.

Lumen, 12, 167-176. https://doi.org/10.7202/1012589ar

Copyright (c) Canadian Society for Eighteenth-Century Studies / Sociéte canadienne d'étude du dix-huitième siècle, 1993
Ce document est protégé par la loi sur le droit d'auteur. L'utilisation des services d'Érudit (y compris la reproduction) est assujettie à sa politique d'utilisation que vous pouvez consulter en ligne.

https://apropos.erudit.org/fr/usagers/politique-dutilisation/ 


\section{Flora Feministica: Reflections on the Culture of Botany}

In 1786 The New Lady's Magazine carried a 'short colloquy' about botany as a science for women:

\section{Ingeana}

How charming these snow-drops still look; notwithstanding the late frost, and the depth of the snow, with whose whiteness they seem to vie.

\section{Flora}

The snow, my dear, has preserved both their beauty and life; otherwise they must have fallen a sacrifice to the severity of the weather.

\section{Ingeana}

What elegant simplicity and innocence in this flower! It belongs, I believe, to the sixth class of the Linnean system, called Hexandria, and by our botanical society Six Males, and to the first order of that class: but it seems to me to be two flowers, a less within a greater.

\section{Flora}

The whole is but one flower; this part, which you suppose to be a lesser flower, is called by our ingenious translators of the immortal Linneus, the nectary; and indeed emphatically; for if the bee were now stirring, you would see him drink his honey out of it.

\section{Ingeana}

I have often admired the green streaks on each of these shorter petals of the nectary; eight in number; which through a microscope swell on the eye like a piece of beautiful fluted work: but we are called.-(177)

In this botanical conversation, Ingeana and Flora speak the dominant language of eighteenth-century botany, using categories and terminology associated with the botanist Linnaeus. Their references are to plant classification and nomenclature rather than to plants as emblems, ornaments, or items of horticultural interest. 


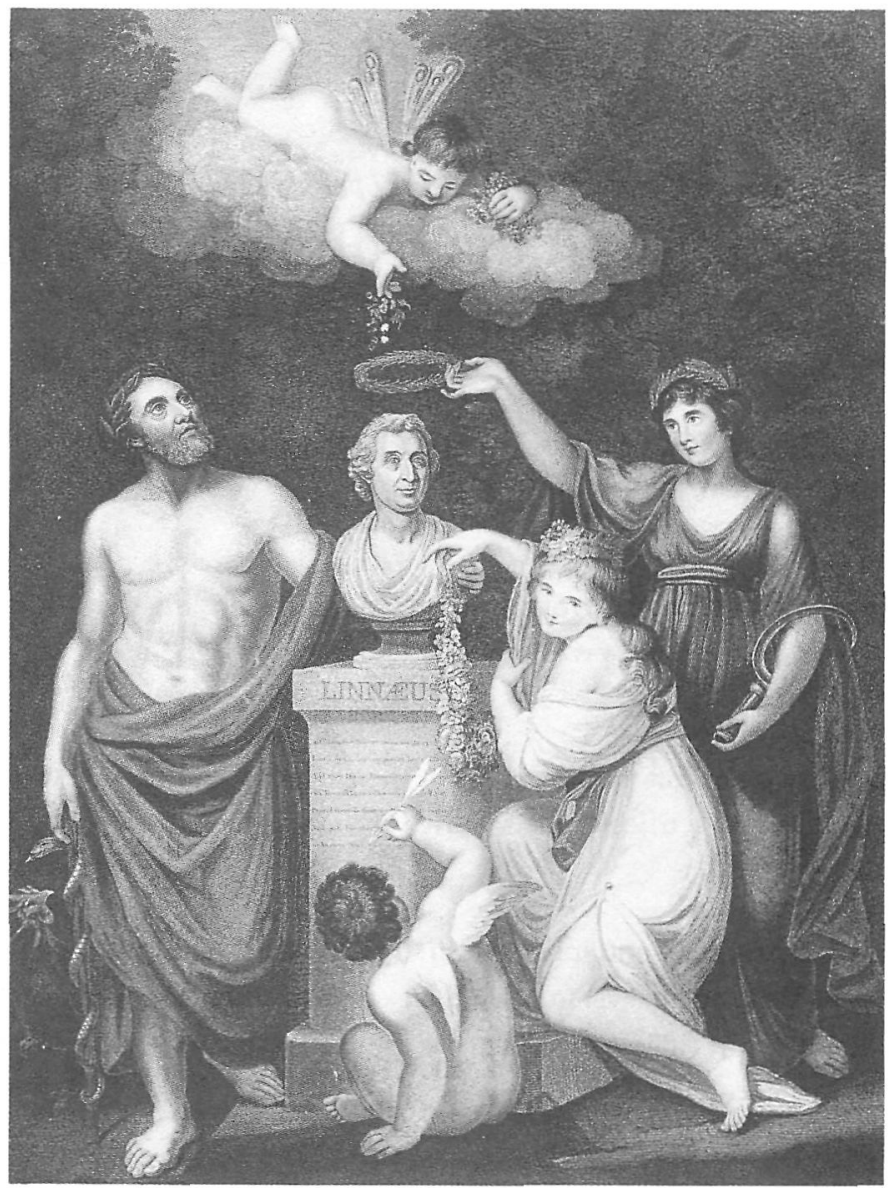

Robert Thornton, 'Aesculapius, Flora, Ceres and Cupid honouring the Bust of Linnaeus' (1799) [Copyright British Museum]

Flora and Ingeana, exemplary women in this conversation, are but one contemporary representation of women in botanical culture in England during the late eighteenth and early nineteenth centuries. 'Flora' appeared in many guises at that time. She was the Goddess of the Vegetable Kingdom, a richly gendered typology depicted, for example, in 'Aesculapius, Flora, Ceres and Cupid honouring the Bust of Linnaeus,' in Robert Thornton's Temple of Flora (1799). She was, as well, an approach to studying nature, and a type of scientific book; a Flora in the late eighteenth century (e.g., William Curtis's Flora Londinensis) used Linnaean categories to list and describe plants in a geographical area. Flora was also a woman in her particularity, a student of Linnaeus, a 
botanical researcher and writer, for botany was a scientific and literary activity for actual women in England from the Enlightenment into the Romantic and Victorian eras. My discussion emphasizes this more materially based aspect of women and botanical culture because I believe that research on women's writing and women's history needs to stay grounded. As we dig gender analyses deeply into the soil of literary and cultural history and the history of science, as we do sophisticated soil analyses in our intellectual and political terrain, as we turn over the older categories, letting them compost into new interpretive riches-as we do our work, I would not have us forget the women and their individual stories. To this end, I highlight the writing of Agnes Ibbetson (1757-1823) and Elizabeth Kent (1790-1861), two interlocutors in botanical conversations of their day.

In late eighteenth-century England botany was a fashionable science across a broad social band, an activity of choice in the public sphere of emerging scientific institutions and also in domestic and familial settings. The Linnaean Sexual System for classifying and naming plants had done much to 'spread botanical knowledge throughout the land' in England after 1760, but the popularity of botanical study also traces to other cultural configurations. The influx of exotic plant materials into Europe formed part of the climate for this story, as did Enlightenment emphases on a Culture of Improvement and enhanced access to scientific knowledge. Periodicals such as the Gentleman's Magazine promoted botanical handbooks and botanical gardens, and they carried discussions about how to make Latin botanical terminology more accessible to general readers, including women. Material conditions in middle-class society shaped botanical culture in late Enlightenment England. As part of the commercialization of leisure, families bought botanical games to teach their children how to name and categorize indigenous plants. Reading publics enlarged, and publishers cultivated diverse audiences hungry for books about astronomy, natural philosophy, and botany.

Encouraged by parents, teachers, and social commentators, and based upon their own interests, many girls and women of the middle and upper social strata took part in botanical conversations. In previous centuries women had developed botanical expertise through herbal practices (Schiebinger; Ginzburg). By the mid-eighteenth century, however, hands-on herbal knowledge faded for middle-class women, replaced by other kinds of botanical knowledge and botanical practices. Botany came to have a range of aesthetic, pedagogical, socia1, and economic uses and values for women, and they expressed interest in botany through various cultural vocabularies. In particular, women wrote books and essays about botany. These writings vary in genre and in their larger concerns. They include introductory books for children and for women, and expositions 
for an adult audience, or for a mixed audience. Some books went through many editions, and several authors, notably Priscilla Wakefield and Jane Marcet, were well known. Through books such as Wakefield's An Introduction to Botany (1796), women shaped an early textbook tradition in science. They specialized in writing books in the 'familiar' format of home-based letters and conversations for young readers and their families. These books, often with a maternal narrator, combine scientific information and moral guidance, presenting a science such as botany as an antidote to 'accomplishments.' In the taxonomy of women's scientific writing in the eighteenth and nineteenth centuries, introductory books were the largest category of literary production.

Among women's early scientific writings we find more than just popular writing or introductory writing for young people, however. Agnes Ibbetson, for example, was Flora as an experimental plant physiologist, whose print medium of choice was the epistolary scientific report. Although she is unknown to us now, 'Mrs. Agnes Ibbetson' had standing enough to be given an obituary in the Gentleman's Magazine and an entry in the Dictionary of National Biography. A serious and committed botanist who worked in isolation, with no apparent networks, Agnes Ibbetson wrote over 50 essays for Nicholson's Journal of Natural Philosophy, Chemistry and the Arts, the Philosophical Magazine, and Annals of Philosophy, general science magazines that published communications from correspondents. These show a turn away from Linnaean systematics and from a natural history tradition of description and classification. Her work bridged observational and experimental methods. She dissected plants ('cut vegetables') over many years, and relied on extensive use of microscopes. (In this she wrote herself into an older story of women from the late seventeenth century on who used microscopes and telescopes for popular science study.)

In botanical essays published between 1809 and 1822, Agnes Ibbetson set out her pursuit of what she called 'the course of Nature.' By means of regular and progressive dissection, she studied the growth of plants, watching the changes through the seasons and over a period of years. Her essays detail her work methods as a way to defend her findings and establish the authority of her assertions. Far removed from botany as delicacy, Ibbetson's botany was the pursuit of exactitude-she dissected 86 trees for one experiment. 'I use almost as many different sorts as a surgeon,' she wrote, and details how she was 'at last driven to the necessity of inventing and contriving' her own tools to be able to 'cut vegetables' more precisely (Nicholson's Journal 33:10). She wrote: 'I may without exaggeration say, that I believe no one has ever dissected or watched plants with the unwearied diligence and patience that I have; taking up a fresh plant of the same kind every three days for nearly four 
years following, watching the interior picture, and pursuing each ingredient from its first formation to its perfection, and hence to its destruction' (Philosophical Magazine, 48:97). Her accounts of her work habits recall Nobel-Prize winner Barbara McClintock, a dedicated observer, who had 'a feeling for the organism,' watched her plants daily over many years, and was committed to letting Nature show itself to her (Keller).

Agnes Ibbetson believed that she had substantial contributions to make to botany, indeed that she had made discoveries about plant physiology. She opposed two central beliefs of the plant physiology establishment: that sap circulates in plants, and that plants 'perspire.' She dismissed the view that plants have sensitivity and volition, and supported mechanical explanations of plant functions. An experimentalist, rather than an animalist, Agnes Ibbetson believed that plants are 'machines governed wholly by light and moisture; and dependent on these causes for motion' (Nicholson's Journal 24:114). Neither deferential nor apologetic in setting out her ideas, she contested the findings of arbiters of botany in her day, among them Jussieu, Thomas Knight, and James E. Smith.

During the years 1809-22, Agnes lbbetson was the only woman to publish papers in Nicholson's Journal and the Philosophical Magazine, and acknowledged that her assertions about Vegetable Life will appear as 'bold language, especially in a woman' (Philosophical Magazine 48:283). Agnes Ibbetson's central contentions were partly right and partly wrong; in that she did not differ from other botanists who were disputing and jockeying for primacy over issues such as plant nutrition and plant motion. But she was an outsider who had no mentor, no buffers, no champion within the ranks of public botanical culture. Gender issues no doubt shaped her relationship to botanical culture.

At the turn of the nineteenth century it was congruent with gender ideology for women to collect plants, dry and draw them, and also to write introductory books for children on a maternal model. Many of 'Linnaeus's daughters' were daughters or wives of botanists, and worked as research assistants, illustrators, teachers, and popular writers (Shteir). For Agnes Ibbetson, by contrast, botany was her all-embracing study, and her commitment to science and methodological rigor went beyond 'appropriate' limits.

Agnes Ibbetson probably began with polite botany during the $1770 \mathrm{~s}$ and 1780s. Born into a merchant family in London, she attended a finishing school, and her early life, according to a contemporary, was 'devoted to gaiety, frivolity, and dissipation.' Married to a barrister who died in 1790 after a long illness, and probably childless, she turned to 'severer pursuits' in her middle years (Webb 53-4). She lived in Devon on a comfortable annuity, and manuscript journal entries give glimpses of a quiet and studious life, in residence with a sister. Her 'usual morning 
employments' included mineralogy, experiments in galvanic electricity, and botany (Mss. IBB). During the second half of her life, botany was Agnes Ibbetson's favorite pursuit, a pursuit to which she devoted ' 13 out of 24 hours,' by her own testimony.

Agnes Ibbetson conducted her botanical research during decades when botany was beginning to change from the amateur activity of generalists into a more specialized activity of proto-professionals. She published her research findings in mid-range scientific periodicals, but was unsuccessful in having her work appear in the Transactions of the Royal Society. At her death Agnes Ibbetson left an unpublished 'Botanical Treatise,' with a prefatory Address to the Public, probably written in the early 1820s, which offers a poignant overview of her career. There she wrote:

Aweful as it is, as it must be to a woman to present to the Public a work of science: The reflection that it is the result of near 16 years hard study can alone give me courage to offer it. The apparently daring plan of altering a science in all its parts from my own knowledge may revolt... But with all humility, I may declare I never thought or imagined such a scheme, my whole Idea consisted in dissecting plants, and by never ceasing attention, care, and labour follow all the yearly changes both without and within the plant, in order to discover the course of nature thus hidden in her secret paths: ....I present then the child of my old age to the public, and though the kind and favourable manner a mutilated part of this work was received has given me courage to complete it, yet I shall make use of no supplications, no excuses, no deprecatory speeches in favor of the work: The love I have for the science, instigated me to write it .... (Mss. IBB)

Agnes Ibbetson was a Scientific Lady - and an aged Scientific Lady at odds with her culture. Writing botanical reports as an experimentalist who wanted to be read by the male establishment as a fellow botanist, she had a palpable sense of grievance about the poor reception of her work.

Elizabeth Kent, author of books and periodical essays, and one generation younger than Agnes Ibbetson, cast her writing about plants in a more Romantic mode. Her publishing career began with books whose languages of nature were horticultural and literary, rather than botanical. Her first book, Flora Domestica, or the Portable Flower Garden (1823), describes flowers, shrubs, and small trees that can be grown in pots or tubs, indoors, on flower-stands, and balconies. Kent wrote for town-dwellers, giving tips about cultivation, propagation, and watering. Flora Domestica also discusses poetic, folkloric, and mythological associations of plants, and includes classical and contemporary poets. The result is a sizeable compilation of contemporary Romantic verse. 
Elizabeth Kent also combined plants and Romantic verse in Sylvan Sketches; or a Companion to the Park and Shrubbery (1825), which describes eighty common hardy trees and shrubs, and explores historical and literary topics relating to trees. The book features spiritual and aesthetic effects of trees, but also is, as it were, rooted in specifics. A long entry on the elm tree, for example, describes several types of Ulmus, surveys uses of the tree, and then goes on to discuss the elm tree beetles which had already infested elms in St. James's and Hyde Parks, London, during the 1820 s.

Starting in 1828, Elizabeth Kent wrote a series of articles about Linnaean botany for John Claudius Loudon's newly-founded journal The Magazine of Natural History. In nine essays she set out the basics of Linnaean taxonomy, teaching how to identify plants, and illustrating the Linnaean System by reference to indigenous British genera. Kent's series was meant to make botany, along with natural history in general, appealing to young people, especially to young women. Her account of the value of botany melds an anti-utilitarian generalist theme with Romantic assertions about nature. Kent often sounds Wordsworthian notes of 'tranquillity' and 'refreshment,' declaring that the 'study of the vegetable world has something of that soothing power which we experience from its actual presence' (1828, I: 132). Calling Linnaeus the 'great sovereign' of botanists, she defends Linnean botany against those who repudiate it as only names and systematics. Names are just one branch of botany, she explains, and learning botanical systematics is akin to learning a foreign grammar, so that one can use it for larger purposes. In this case, the grammar of botany leads into the language of poetry.

Elizabeth Kent belonged to the culture and personal networks of Romanticism. She was the sister-in-law to the essayist and editor Leigh Hunt, and his principal correspondent during the years that the Hunt family lived in Italy in the company of Shelley and Byron (Tatchell; Hunt, Correspondence). Her first book developed from her relationship with Leigh Hunt, who suggested and translated verses for inclusion in Flora Domestica, and sent many editorial suggestions. Hunt also reviewed Flora Domestica for the Examiner. He described the book as 'tying up its lady-like bunches with posies and ends of verses,' and commented on how appropriate it was that a woman should teach the care of flowers: 'No pretension is made to anything great; but a great deal is done, which is very pretty and small' (303-04). Leigh Hunt, Romantic, sought to bring flowers and gardening within the masculine ken, and hence his review of Flora Domestica highlighted how gentlemen writers of past and present love flowers and gardens. This enlargement of gender ideas was far more advantageous to men than 
to women, giving men latitude in taste and activities, while relegating women to the tidy, small, and pretty. Hunt's gendered remarks about Flora Domestica illustrate the Romantic climate in which Elizabeth Kent produced her books, and then went on to write her Linnaean essays for the Magazine of Natural History.

By the 1820s and 1830s, Romantic writing as well as an anti-Linnaean direction in botany had diversified the languages of nature in books, essays, and poetry about plants. Women writers began shaping a Language of Flower tradition for an English-language audience in a cultural semiotic that had more to do with emblems and personifications than with plants. Elizabeth Kent's books from the 1820s are transitional between earlier, more systematic accounts of plants (conventional taxonomic Floras) and later, more literary accounts. Her essays for the Magazine of Natural History also show that the cultural turn from popular systematic botany toward more literary writing about plants did not exclude introductory and expository accounts about botany. In botany writing, as in other introductory books in natural history and popular science, the task for authors was to find languages and formats for teaching. Kent's botanical work was based in an interest in plants in themselves rather than in plants as principally signs for reflection or imagination. Leigh Hunt, Romantic, referred to 'these profuse and beautiful thoughts of Nature, called "flowers"' (Autobiography 3: 210). Elizabeth Kent, Romantic, wrote about plants in themselves, and her attention to actual specimens is an important feature of her writing. In this, she echoed poetry by women during the Romantic period that is characterized by closely observed quotidian particulars rather than by the large visionary fields of male Romantic poets (Curran 189-90). Her writings challenge and enlarge how we characterize Romantic writing.

Elizabeth Kent appeared as an author on the public scene for a brief eight years between 1823-31. During that time, her two books-both published anonymously - went through several editions. Other projects were pursued and proposed (including a book on birds with John Clare), but nothing else was published on plants or natural history. In 1828 Elizabeth Kent advertised in the Times about giving young ladies instruction in the science of botany. She probably turned to teaching to earn money; in later years she was a governess. (After 1831, with thirty years of life still in front of her, Kent dropped from public authorship. She received little income from her writing, and by 1848, 'in a state of penury,' found a home with a nephew.)

It is not surprising that Elizabeth Kent became a teacher of botany, for she was fond of flowers in both their generality and their specificity. Near the end of her introductory essay in the Magazine of Natural History 
Kent raised an issue about the status of women and botanical culture by interjecting a complaint about women and botanical gardens. In her day, students of botany who wanted to move beyond indigenous plants into studying exotics could find many collections in private botanical gardens in the environs of London. Kent complains about how little the proprietors of these 'imported gardens' assist women who want to learn about plants. Female visitors, she explains, are guided through these gardens too quickly, generally accompanied by 'some ignorant lad, who is incompetent to reply to any question put to him, as to the plants, their names, countries, habits, \&c.' Kent does not mask the personal experiences that fueled her annoyance. She writes:

On some occasions, after asking several questions of the youth who attended our party, and finding that he could not answer them; that even the answers he did give were not correct; I desisted altogether from seeking the knowledge which I went purposely to obtain, and returned but little wiser. On one occasion, our party was accompanied by an able and experienced botanist; but there were older persons than ourselves, and gentlemen, in company, who, of course, engrossed the whole of his time and attention; and those who were ... the most interested in obtaining, the information he might communicate, were precisely those who learned nothing from the visit but what their own eyes could teach them. (1828, I:133-34; italics mine)

Kent's acute account of gender politics in botanical gardens shows that botanical women in the 1820 s were caught between a "ladies"' culture of plants as beauty or plants as popular, and a male culture of gentlemanly botany. In fact the status of botanical women became more problematic as gender configurations around women and botany changed across the nineteenth century.

Botanical writers like Agnes Ibbetson and Elizabeth Kent textualize the history of women and botanical culture in England during the late eighteenth and early nineteenth centuries, and offer material for historically specific gender analyses. After 1830, the history of botanical culture is a history of how ideas linked to a 'masculine' notion of science crowded out ideas linked to a 'feminine' notion of science. A 'masculine' face of botany turned away from an amateur natural history tradition of collectors and field workers, and over the next decades became science based in laboratories and lecture halls. The botanical conversations of many nineteenth-century Floras and Ingeanas increasingly were interrupted as a result. 


\section{Works Cited}

Boulger, G.S. 'Mrs. Agnes Ibbetson.' Dictionary of National Biography. 1891 ed.

Curran, Stuart. 'Romantic Poetry.' Romanticism and Feminism. Ed. Anne K. Mellor. Bloomington: Indiana UP, 1988.

Examiner. 19 December 1824: 303-4.

Ginzburg, Ruth. 'Uncovering Gynocentric Science.' Feminism and Science. Ed. Nancy Tuana. Bloomington: Indiana UP, 1989.

Hunt, Leigh. Correspondence of Leigh Hunt. 2 vols. London, 1862.

-. The Autobiography of Leigh Hunt. 3 vols. London, 1850.

Ibbetson, Agnes. 5 vols. Mss. IBB. (Botany Library, Natural History Museum, London)

—. Nicholson's Journal 24 (1809):114-23; 33 (1812):1-10.

—. Philosophical Magazine 48 (1816): 96-111; 278-286.

Keller, Evelyn Fox. A Feeling for the Organism: The Life and Work of Barbara McClintock. New York: Freeman, 1983.

Kent, Elizabeth. Magazine of Natural History. 1828-30. passim.

-. Flora Domestica. or the Portable Flower Garden. London, 1823.

-. Sylvan Sketches; or a Companion to the Park and Shrubbery. London, 1825.

'Mrs. Agnes Ibbetson,' Gentleman's Magazine 93 (1823):474.

New Lady's Magazine; or, Polite and Entertaining Companion for the Fair Sex. May 1786.

Schiebinger, Londa. The Mind Has No Sex? Women in the Origins of Modern Science. Cambridge, MA: Harvard UP, 1989.

Shteir, Ann B. 'Linnaeus's Daughters: Women and British Botany.' Women and the Structure of Society. Ed. Barbara J. Harris \& JoAnn K. McNamara. Durham, NC: Duke UP, 1984. 67-73.

-. 'Botany in the Breakfast Room.' Uneasy Careers and Intimate Lives: Women in Science, 1789-1979. Ed. Pnina G. Abir-Am and Dorinda Outram. New Brunswick, NJ: Rutgers UP, 1987. 31-43

Tatchell, Molly. Leigh Hunt and his Family in Hammersmith. London: Hammersmith Local History Group, 1969.

Webb, Rev. William. Memorials of Exmouth. 1872. 